\title{
The nature and epidemiology of $\operatorname{Oqx} A B, a$ multidrug efflux pump
}

\author{
Jun Li $i^{1,2}$, Heying Zhang ${ }^{1}$, Jianan Ning ${ }^{1}$, Abdul Sajid ${ }^{1,4}$, Guyue Cheng ${ }^{3}$, Zonghui Yuan ${ }^{1,3^{*}}$ and Haihong Hao ${ }^{1,3^{*}}$
}

\begin{abstract}
Background: OqxAB efflux pump has been found to mediate multidrug resistance (MDR) in various bacteria over the past decades. The updates on the nature and epidemiology of OqxAB efflux pump need to be fully reviewed to broaden our understanding of this MDR determinant.

Methods: A literature search using the keyword of "oqXAB" was conducted in the online databases of Pubmed and ISI Web of Science with no restriction on the date of publication. The 87 publications were included into this review as references due to their close relevance to the nature and/or epidemiology of OqxAB efflux pump.

Results: The oqXAB gene generally locates on chromosome and/or plasmids flanked by IS26-like elements in clinical isolates of Enterobacteriaceae and Klebsiella pneumoniae, conferring low to intermediated resistance to quinoxalines, quinolones tigecycline, nitrofurantoin, several detergents and disinfectants (benzalkonium chloride, triclosan and SDS). It could co-spread with other antimicrobial resistance genes (bla $a_{\mathrm{CTX}-\mathrm{M},} r m+B$ and $a a c\left(6^{\prime}\right)-1 b$ etc.), virulence genes and heavy metal resistance genes (pco and sil operons). Both RarA (activator) and OqxR (repressor) play important roles on regulation of the expression of OqxAB.

Conclusions: The dissemination of oqxAB gene may pose a great risk on food safety and public health. Further investigation and understanding of the natural functions, horizontal transfer, and regulation mechanism of the OqxAB efflux pump will aid in future strategies of antimicrobial usage.
\end{abstract}

Keywords: oqxAB, Multidrug efflux pump, Quinoxalines, Quinolones, Tigecycline, Nitrofurantoin

\section{Background}

Antimicrobial resistance has posed increasing challenge to public health [1]. Efflux pumps are found in almost all bacterial species and have important roles on both intrinsic and acquired resistance to antimicrobials by lowering intracellular antibiotic concentration and promoting site mutation accumulation [2,3]. Most of the efflux pumps are located on the chromosome of bacteria [4]. Plasmidmediated efflux pumps have been described in recent years, such as QacBIII [5], Tet(L) [3] and MexCD [6] efflux pumps.

In 2004, a novel plasmid-encoded multidrug efflux pump OqxAB was firstly identified on the pOLA52 plasmid in E. coli from swine manure in Denmark [7].

\footnotetext{
* Correspondence: yuan5802@mail.hzau.edu.cn; yuanzongh@126.com; haohaihong@mail.hzau.edu.cn

${ }^{1}$ National Reference Laboratory of Veterinary Drug Residues (HZAU) and Key Laboratory of the Detection for Veterinary Drug Residues, Wuhan 430070, Hubei, China

Full list of author information is available at the end of the article
}

The prevalence of $o q x A B$ among Enterobacteriaceae have been increasingly reported over the past decades (Tables 1, 2 and 3) [8]. The overexpression of OqxAB confers resistance to multiple drugs (quinoxalines, quinolones, tigecycline, nitrofurantoin and chloramphenicol), detergents and disinfectants (benzalkonium chloride, triclosan and SDS). This plasmid-borne multidrug efflux pump may pose a resistance problem, because it could facilitate the development of resistance to multiple drugs and dissemination of antimicrobial resistance via horizontal transfer.

Till now, several reviews have summarized the current knowledge of plasmid-mediated quinolone resistance (PMQR) genes, but there are no reviews specifically focused on the OqxAB efflux pump. A comprehensive understanding of the nature and epidemiology of this OqxAB efflux pump will benefit for future strategies of optimizing antimicrobial use and development of anti-resistance interventions. In this paper, a literature 
search was conducted using the online databases of Pubmed (www.ncbi.nlm.nih.gov/entrez/query.fcgi; 1809 until present) and ISI Web of Science (http://www.isiwe bofknowledge.com; timespan 1945 until present) with no restriction on the date of publication. A total of 117 relevant publications were identified using the keyword "oqxAB". Eighty-seven of the publications with close relevance to the nature and/or epidemiology of OqxAB efflux pump were included in this review as references. The updates on the genetic characteristics, prevalence of the OqxAB multidrug efflux pump in various bacterial species and its contribution on multidrug resistance were fully reviewed.

\section{Genetic characteristics and regulation of oqxAB operon}

The plasmid-borne OqxAB efflux pump has been reported since 2004. Sørensen et al. isolated an Escherichia coli $(E$. coli) from swine manure in a farm using olaquindox as a feed additive [9]. Using agar dilution test with Sensititre plates, they found that this isolate was resistant or has reduced susceptibility to a number of antibiotics, including olaquindox (OLA; MIC $128 \mathrm{mg} / \mathrm{L}$ ), carbadox (CBX; MIC $128 \mathrm{mg} / \mathrm{L}$ ), ampicillin (AMP; MIC $32 \mathrm{mg} / \mathrm{L}$ ), kanamycin (KAN; MIC $64 \mathrm{mg} / \mathrm{L}$ ), chloramphenicol (CHL, MIC $64 \mathrm{mg} / \mathrm{L}$ ), streptomycin (STR; MIC $128 \mathrm{mg} / \mathrm{L}$ ), sulfamethoxazole (SXT; MIC $512 \mathrm{mg} / \mathrm{L}$ ) and trimethoprim (TMP, MIC $32 \mathrm{mg} / \mathrm{L}$ ). Through filter conjugation, the reduced susceptibility to ampicillin, chloramphenicol and olaquindox could be transferred to the recipient strain E. coli $\mathrm{CSH} 26$, while the resistance to kanamycin, streptomycin, sulfamethoxazole, trimethoprim and carbadox were not transferred. The transconjugants received a plasmid from the donor strain and this $52 \mathrm{~kb}$ plasmid was later named as pOLA52 [9].

Subsequently, Hansen et al. [7] subcloned and sequenced the genetic elements of this conjugative plasmid pOLA52 and found the genetic elecments was composed of three open reading frames encoding putative proteins (Fig. 1). Two of the proteins designated as OqxA and OqxB were highly homologous to efflux pumps from the RND family in other bacterial species. By homology modeling using the software of SYBYL X-2.0, we found that the positions and numbers of the transmembrane helices in the crystal structure of OqxB was highly consistent with AcrB protein in E. coli, MexB protein in Pseudomonas aeruginosa, $\mathrm{CmeB}$ protein in Campylobacter jejuni, AdeB protein in Acinetobacter baumannii and MtrD protein in Neisseria gonorrhoeae (Fig. 2). The ORF3 was homologous to a putative transcriptional regulator and may be involved in the regulation of $o q x A B$ operon. The plasmid pLOW2::oq $x A B$ in E. coli strain $\mathrm{N} 43$ was found to be a $\mathrm{H}$-driven ethidium bromide efflux and showed high-level resistance to olaquindox
(OLA; $\mathrm{MIC}>128 \mathrm{mg} / \mathrm{L}$ ) and chloramphenicol (CHL; $\mathrm{MIC}>64 \mathrm{mg} / \mathrm{L}$ ), while the control plasmid (pLOW2) in E.coli N43 only presented low-level resistance to olaquindox (OLA; MIC $8 \mathrm{mg} / \mathrm{L}$ ) [7]. This is the first report of a plasmid-encoded multidrug efflux pump conferring resistance to olaquindox [7].

A gene cassette (mrkABCDF) was also identified on the pOLA52, which was in relation to the bacterial functions of type 3 fimbriae expression and biofilm formation [10]. When the mrk operon was inactivated, the conjugative transfer ability of pOLA52 was also remarkably reduced. In 2008, the complete sequence of pOLA52 was analyzed and annotated [11]. The 51,602 bp conjugative plasmid contained 68 putative genes, which were associated with functions of conjugation, replication and partitioning. Half of these genes constituted a conserved IncX1-type backbone. A fragmented Tn 3 transposon encoded resistance to ampicillin. The RND family efflux pump encoding gene $o q x A B$ and the biofilm formation involved gene mrkABCDF were located on two composite transposons (Tn6010 and Tn6011) [11].

Tn6010-associated $o q x A B$ was detected in Klebsiella spp. and Raoultella spp. by a reliable two-step PCR-based method [12]. Chromosome-borne oq $x A B$ was identified in Klebsiella spp. and Raoultella spp. by hybridization with I-CeuI-restricted genomes [13]. A recent study of the evolution and dissemination routes of the oq $x A B$-like elements among different bacterial species found that the $\operatorname{oq} x A B$ gene was detected in the chromosome of all tested $K$. pneumoniae, even those isolated before the year of 1984, supporting that the plasmid-borne $o q x A B$ was most likely to be acquired from the chromosome of $K$. pneumoniae and Raoultella spp. [13]. The sequence of chromosome-based $o q x A B$ in K. pneumoniae was highly homologous to the sequence of plasmid-based $o q x A B$ in E. coli (e.g pOLA52) and Salmonella isolates, while low homologous to that in Enterobacter spp. [13] Novel mutants named as oqxA2, $o q x B 2$ and $o q x B 3$ were identified in K. pneumoniae [14]. A number of plasmid replicons were able to transfer the $o q x A B$ gene, including IncF, IncH, IncI, IncHI2 and IncX [11, 15-18]. IS26-like insertion sequences flanked the $o q x A B$ operon and the local repressor gene $o q \times R$ might be mobilized as part of a $6731 \mathrm{bp}$ composite transposon known as Tn6010 [19] (Fig. 1). The nimC element, blmS bleomycin resistance gene and transposition elements IS26 and Tn3 were located on the upstream of Tn6010 in Salmonella, indicating the possibility of transposition of an entire 10-kb fragment from pOLA52 [20].

Many transcriptional regulators, like MarA, SoxS, RamA and Rob, have been reported to upregulate the expression of the RND type efflux pumps in Enterobacteriaceae, thus contributed to the MDR phenotype [21]. 
Table 1 Epidemiology of oqxAB in in Escherichia coli and Enterobacter cloacae

\begin{tabular}{|c|c|c|c|c|c|c|}
\hline References & $\begin{array}{l}\text { Year(s) of } \\
\text { isolates } \\
\text { collection }\end{array}$ & Geographic area & Sample source & $\begin{array}{l}\text { Percentage of oqxAB } \\
\text { carring isolates } \\
\text { (no. of isolates) }\end{array}$ & $\begin{array}{l}\text { Resistance } \\
\text { phenotype(s) }\end{array}$ & Descriptions \\
\hline [27] & $\begin{array}{l}1995- \\
1998\end{array}$ & Danmark, Swedish & Swine & $\begin{array}{l}11.84 \% \\
(27 / 228)\end{array}$ & OLA & $\begin{array}{l}\text { oqXAB operon was situated } \\
\text { on pOLA52 plasmid in most } \\
\text { strains. }\end{array}$ \\
\hline [17] & 2002 & Guangdong, China & $\begin{array}{l}\text { Swine, chicken, } \\
\text { environment, } \\
\text { farmworker }\end{array}$ & $\begin{array}{l}\text { Animals: E. coli: } 39.8 \% \\
\text { (39/98), environment: } \\
\text { E. coli:43.9\% (18/41), } \\
\text { farmworkers: } \\
\text { E. coli:30.3\% (10/33) }\end{array}$ & $\begin{array}{l}\text { MEQ, OLA, } \\
\text { CHL, ENR, } \\
\text { CIP, AMP, } \\
\text { KAN, TET, } \\
\text { SXT }\end{array}$ & $\begin{array}{l}\text { oqxAB was associated with } \\
\text { IS } 26 \text { and was carried on the } \\
43-\text { to } 115-\mathrm{kb} \text { IncF transferable } \\
\text { plasmid. }\end{array}$ \\
\hline [31] & $\begin{array}{l}2012- \\
2014\end{array}$ & Zhengzhou, China & Dog, cats, human & $\begin{array}{l}\text { Dogs: E. coli:58.5\% } \\
(62 / 106), \\
\text { cats: E. coli:56.25\% (36/64), } \\
\text { human: E. coli:42.0\% (42/100) }\end{array}$ & $\begin{array}{l}\text { OLA, MEQ, } \\
\text { CIP, TET, } \\
\text { FFC }\end{array}$ & $\begin{array}{l}\text { Several oqxAB-positive isolates } \\
\text { have high similarity and the } \\
\text { oqxAB gene was primarily located } \\
\text { on plasmids. }\end{array}$ \\
\hline [32] & $\begin{array}{l}1970 s- \\
2013\end{array}$ & $\begin{array}{l}\text { North and South } \\
\text { China }\end{array}$ & $\begin{array}{l}\text { Chicken, pig, } \\
\text { duck, goose }\end{array}$ & E. coli:28.7\% (322/1123) & MEQ & $\begin{array}{l}\text { IS26-flanked Tn6010 element } \\
\text { was prone to excision via IS26- } \\
\text { mediated recombination. }\end{array}$ \\
\hline$[40]$ & $\begin{array}{l}2011- \\
2013\end{array}$ & Guangdong, China & $\begin{array}{l}\text { Pig, chicken, } \\
\text { retail meat, } \\
\text { humans }\end{array}$ & $\begin{array}{l}\text { Animals: E. coli: } 33.8 \% \\
(172 / 509), \\
\text { food: E. coli: } 17.3 \%(60 / 346), \\
\text { human: E. coli: } 18.1 \%(90 / 498)\end{array}$ & $\begin{array}{l}\text { NEO, APR, } \\
\text { FFC, OLA, } \\
\text { TET, SXT }\end{array}$ & $\begin{array}{l}\text { oqxAB was located on plasmids } \\
\text { belonging to IncN1-F33:A-:B-, } \\
\text { InCHI2/ST3, F-:A18:B-, F-:A-:B54 }\end{array}$ \\
\hline [41] & $\begin{array}{l}2010- \\
2011\end{array}$ & China & Human & E. coli:3.8\% (23/590) & CIP, LVX & $\begin{array}{l}\text { oqxB20 and oqxB29 were } \\
\text { identified. }\end{array}$ \\
\hline [43] & $\begin{array}{l}2001- \\
2015\end{array}$ & Taiwan, China & Human & E. coli:6.05\% (15/248) & CIP, LVX & $\begin{array}{l}\text { oqxAB was located on plasmid } \\
\text { and successfully transferred to } E \text {. } \\
\text { coli C } 600 \text { by conjugation. }\end{array}$ \\
\hline [44] & $\begin{array}{l}2008- \\
2010\end{array}$ & Ujjain, India & $\begin{array}{l}\text { Hospital } \\
\text { wastewater }\end{array}$ & E. coli:1.05\% (2/190) & $\begin{array}{l}\text { CTX, CAZ, } \\
\text { CIP, OFX }\end{array}$ & $\begin{array}{l}\text { First paper reports the detection } \\
\text { of oqxAB-carring E.coli from } \\
\text { hospital wastewater in India }\end{array}$ \\
\hline$[45]$ & $\begin{array}{l}1993- \\
2010\end{array}$ & China & $\begin{array}{l}\text { Human, animals, } \\
\text { environment }\end{array}$ & $\begin{array}{l}\text { Human: E. coli:5.2\% } \\
\text { (16/307), } \\
\text { chicken: E. coli: } 19.8 \% \\
\text { (76/384), } \\
\text { pigs: E. coli:51\% (101/198), } \\
\text { environment: E. coli: } 20.5 \%(9 / 44)\end{array}$ & $\begin{array}{l}\text { AMP, TET, } \\
\text { SXT, CHL, } \\
\text { STR, CIP }\end{array}$ & $\begin{array}{l}\text { First report of oqxAB-positive } \\
\text { isolates from ducks and geese } \\
\text { and as early as } 1994 \text { from } \\
\text { chickens. }\end{array}$ \\
\hline [48] & $\begin{array}{l}2004- \\
2011\end{array}$ & $\begin{array}{l}\text { Guangdong, Anhui, } \\
\text { Guangxi, Henan, } \\
\text { Jiangsu, Sichuan, } \\
\text { Fujian, Jiangxi, } \\
\text { Beijing, China }\end{array}$ & $\begin{array}{l}\text { Pigs, chickens and } \\
\text { ducks), companion } \\
\text { animals, human, } \\
\text { retail meat }\end{array}$ & $\begin{array}{l}\text { Pig: E. coli:55.7\% (280/503), } \\
\text { chicken: E. coli:25.8\% (127/493), } \\
\text { duck: E. coli:40.6\% (109/389), } \\
\text { pet: E. coli:10\% (35/353), } \\
\text { food: } \text { E. coli: } 16.2 \%(57 / 352), \\
\text { human: } \text { E. colli:7.2\% (15/207) }\end{array}$ & $\mathrm{CIP}$ & $\begin{array}{l}43.6 \% \text { of the E. coli harbored at } \\
\text { least one PMQR gene. The most } \\
\text { common PMQR gene was oqxAB } \\
(29.3 \%) \text {, followed by qnr }(13.6 \%) \text {, } \\
\text { aac(6')-lb-cr }(11.6 \%) \text {, and qepA } \\
(3.3 \%) \text {. }\end{array}$ \\
\hline [49] & $\begin{array}{l}2002- \\
2010\end{array}$ & Guangdong, China & $\begin{array}{l}\text { Ducks, chickens, } \\
\text { pigs }\end{array}$ & E. coli:43.43\% (215/495) & $\begin{array}{l}\text { CIP, ENR, } \\
\text { LVX, NAL }\end{array}$ & $\begin{array}{l}\text { Prevalence of oqxAB had } \\
\text { significant Spearman correlation } \\
\text { coefficients with MICs of } \\
\text { quinolones. }\end{array}$ \\
\hline$[50]$ & 2011 & $\begin{array}{l}\text { Beijing, Shanxi, } \\
\text { Guangdong, } \\
\text { Inner Mogolia, } \\
\text { China }\end{array}$ & $\begin{array}{l}\text { Chicken carcasses, } \\
\text { ground pork }\end{array}$ & E. coll:62.26\% (66/106) & $\begin{array}{l}\text { CTX, } \\
\text { CIP,CHL, } \\
\text { TET, GEN, } \\
\text { SXT, AMP, } \\
\text { CAZ }\end{array}$ & $\begin{array}{l}68.2 \% \text { of the cefotaxime and } \\
\text { ciprofloxacin coresistant E. coli } \\
\text { isolates carried at least one PMQR } \\
\text { gene and eight subtypes of } \\
\text { bla }_{\mathrm{CTX}-\mathrm{M}} \text { were identified. }\end{array}$ \\
\hline$[46]$ & $\begin{array}{l}2006- \\
2008\end{array}$ & Northern Italy & $\begin{array}{l}\text { Farm and wild } \\
\text { lagomorphs }\end{array}$ & E. coli:15\% (17/113) & $\begin{array}{l}\text { TET, STR, } \\
\text { NAL, SXT, } \\
\text { CHL }\end{array}$ & $\begin{array}{l}\text { Seven out of } 17 \text { strains were } \\
\text { carried from three to six different } \\
\text { plasmid types, such as IncF, } \\
\text { IncHI1, Incl1, IncN, IncP, IncX1, } \\
\text { IncY, and ColE. }\end{array}$ \\
\hline$[16]$ & $\begin{array}{l}2002- \\
2012\end{array}$ & Guangdong, China & $\begin{array}{l}\text { Duck, chicken, } \\
\text { geese and pig }\end{array}$ & E. coli:47.12\% (328/696) & $\begin{array}{l}\text { AMP, } \\
\text { CHL,FFC, } \\
\text { TET, GEN, } \\
\text { KAN, CTI, } \\
\text { DOX }\end{array}$ & $\begin{array}{l}\text { oqXAB, bla } a_{\mathrm{CTX}-\mathrm{M}} \text { and floR were co- } \\
\text { transferred on F33:A-: B- and HI2 } \\
\text { plasmids in E. coli. }\end{array}$ \\
\hline
\end{tabular}


Table 1 Epidemiology of oqxAB in in Escherichia coli and Enterobacter cloacae (Continued)

\begin{tabular}{|c|c|c|c|c|c|c|}
\hline References & $\begin{array}{l}\text { Year(s) of } \\
\text { isolates } \\
\text { collection }\end{array}$ & Geographic area & Sample source & $\begin{array}{l}\text { Percentage of oqxAB } \\
\text { carring isolates } \\
\text { (no. of isolates) }\end{array}$ & $\begin{array}{l}\text { Resistance } \\
\text { phenotype(s) }\end{array}$ & Descriptions \\
\hline [19] & $\begin{array}{l}1998- \\
2006\end{array}$ & Seoul Korea & Human & $\begin{array}{l}\text { E. coll:0.4\% }(1 / 261) \\
\text { E. cloacae: } 4.6 \%(3 / 65) \text {, }\end{array}$ & OLA, CIP & $\begin{array}{l}\text { This is the first report of } \\
\text { the presence of an oqXAB- } \\
\text { containing plasmid in a human } \\
\text { isolate of E. coli. }\end{array}$ \\
\hline [14] & 2010 & Shanghai China & Human & E. coli: $6.6 \%(9 / 136)$ & $\begin{array}{l}\text { NAL, CIP, } \\
\text { NOR, LVX, } \\
\text { OLA, TMP, } \\
\text { CHL, TET }\end{array}$ & $\begin{array}{l}\text { Variants of oqXA2, oqxB2 and } \\
\text { oqxB3 were identified in two } E \text {. } \\
\text { coli strains. }\end{array}$ \\
\hline
\end{tabular}

Notes: OLA olaquindox, MEQ mequindox, CHL chloramphenicol, ENR enrofloxacin, CIP ciprofloxacin, AMP ampicillin, KAN kanamycin, TET tetracycline, SXT sulfamethoxazole-trimethoprim, FFC florfenicol, NEO neomycin, APR apramycin, LVX levofloxacin, CTX cefotaxime, CAZ ceftazidime, OFX ofloxacin, STR streptomycin, GEN gentamicin, CTI ceftiofur, DOX doxycycline, CTX cefotaxime, NAL nalidixic acid

Table 2 Epidemiology of oqxAB in Salmonella spp.

\begin{tabular}{|c|c|c|c|c|c|c|}
\hline References & $\begin{array}{l}\text { Year(s) of } \\
\text { isolates } \\
\text { collection }\end{array}$ & Geographic area & $\begin{array}{l}\text { Sample } \\
\text { source }\end{array}$ & $\begin{array}{l}\text { Percentage of } \\
\text { oqxAB carring } \\
\text { isolates } \\
\text { (no. of isolates) }\end{array}$ & $\begin{array}{l}\text { Resistance } \\
\text { phenotypes }\end{array}$ & Descriptions \\
\hline [58] & & Hong Kong & $\begin{array}{l}\text { Pork, } \\
\text { chicken }\end{array}$ & $2.38(2 / 84)$ & $\begin{array}{l}\text { TET, CHL, } \\
\text { NAL, OLA }\end{array}$ & $\begin{array}{l}\text { First Detection of oqXAB on the chromosomes of } \\
\text { two Salmonella Derby isolates from food. }\end{array}$ \\
\hline$[60]$ & $\begin{array}{l}2005- \\
2011\end{array}$ & $\begin{array}{l}\text { Guangdong, Guangxi, } \\
\text { Henan, Fujian, Sichuan, } \\
\text { Beijing, Shanghai, } \\
\text { Chongqing, China }\end{array}$ & Human & $0.73 \%(4 / 546)$ & $\begin{array}{l}\mathrm{NAL}, \mathrm{CHL} \\
\text { GEN, } \mathrm{KAN}, \\
\text { TET }\end{array}$ & $\begin{array}{l}\text { Combined effects of ESBL determinants and oqXAB } \\
\text { were responsible for the emergence of XDR } S \text {. } \\
\text { Typhimurium. }\end{array}$ \\
\hline [59] & $\begin{array}{l}2009- \\
2013\end{array}$ & Henan, China & $\begin{array}{l}\text { Poultry, } \\
\text { human }\end{array}$ & $\begin{array}{l}72.73 \% \\
(112 / 154)\end{array}$ & $\begin{array}{l}\text { AMP, CAZ, } \\
\text { CHL, CIP, } \\
\text { CTX, GEN, } \\
\text { SXT, TET }\end{array}$ & $\begin{array}{l}\text { Co-occurrence of gepA, oqxAB, and aac }\left(6^{\prime}\right)-1 b \text { - } c r \text { with } \\
\text { mutations in gyrA and parC and several ESBLs were } \\
\text { noteworthy. }\end{array}$ \\
\hline$[62]$ & $\begin{array}{l}1999- \\
2008\end{array}$ & Taiwan, China & Human & $\begin{array}{l}16.1 \% \\
(10 / 76)\end{array}$ & $\begin{array}{l}\text { CIP, LVX, } \\
\text { CAZ, CTX } \\
\text { FOX, CRO }\end{array}$ & $\begin{array}{l}\text { GyrA mutations are the major quinolone } \\
\text { resistance mechanisms in Salmonella. } \\
\text { Overproduction of efflux pump and presence } \\
\text { of qnr and oqxAB play additional roles. }\end{array}$ \\
\hline$[63]$ & $\begin{array}{l}2012- \\
2013\end{array}$ & Shenzhen, China & $\begin{array}{l}\text { Retail } \\
\text { meat } \\
\text { (chicken, } \\
\text { pork) }\end{array}$ & $\begin{array}{l}91 \% \\
(75 / 82)\end{array}$ & $\begin{array}{l}\text { CTX, CIP, } \\
\text { AZM, AMP, } \\
\text { NAL, KAN, } \\
\text { STR, CHL, TET }\end{array}$ & $\begin{array}{l}\text { PMQRs greatly facilitate development of FQs } \\
\text { resistance in Salmonella. }\end{array}$ \\
\hline$[61]$ & $\begin{array}{l}2010- \\
2011\end{array}$ & $\begin{array}{l}\text { Fujian, Henan, } \\
\text { Guangdong, Beijing, } \\
\text { Guangxi, Shanxi, } \\
\text { Sichuan, Shanghai } \\
\text { China }\end{array}$ & $\begin{array}{l}\text { Retail raw } \\
\text { chicken } \\
\text { carcasses }\end{array}$ & $\begin{array}{l}42 \% \\
(194 / 462)\end{array}$ & $\begin{array}{l}\text { NAL, CIP, } \\
\text { LVX, GAT }\end{array}$ & $\begin{array}{l}\text { Isolates which harboured more PMQR genes and } \\
\text { accumulated more point mutations on GyrA and } \\
\text { ParC presented higher resistance levels to quinolones. }\end{array}$ \\
\hline$[15]$ & $\begin{array}{l}2007- \\
2011\end{array}$ & China & $\begin{array}{l}\text { Poultry, } \\
\text { swine, } \\
\text { animal } \\
\text { hospital }\end{array}$ & $\begin{array}{l}31.7 \% \\
(20 / 63)\end{array}$ & $\begin{array}{l}\text { OLA, NAL, } \\
\text { GEN, CHL, } \\
\text { FFC, AMP, } \\
\text { CIF, TET, SMX }\end{array}$ & $\begin{array}{l}\text { All the isolates carring transferable IncHI2-type } \\
\text { plasmids haboured oqXAB cassette and incomplete } \\
\text { class } 1 \text { integron. }\end{array}$ \\
\hline$[64]$ & $\begin{array}{l}2015- \\
2016\end{array}$ & $\begin{array}{l}\text { Shandong, Henan, } \\
\text { Jiangsu, Anhui, Liaoning, } \\
\text { Tianjin, Beijing, Hebei, } \\
\text { Hubei, Guizhou, Xinjiang, } \\
\text { Ningxia, Sichuan, China }\end{array}$ & Chicken & $\begin{array}{l}8.24 \% \\
(14 / 170)\end{array}$ & $\begin{array}{l}\text { CTX, AK, } \\
\text { CIP, AMP, } \\
\text { CTI,FEP, ATM, } \\
\text { STR, NAL, } \\
\text { NOR, SXT, } \\
\text { CHL, TET, DOX }\end{array}$ & $\begin{array}{l}\text { The bla } a_{\text {CTX-M }} \text { genes, } 16 \mathrm{~S} \text { rRNA methylase genes } \\
\text { (armA, rmtD or rmtC) and five plasmid-mediated } \\
\text { quinolone resistance (PMQR) determinants }\left(\operatorname{aac}\left(6^{\prime}\right) \text { - }\right. \\
\text { lb-cr, oqxAB, qnrB, qepA and qnrD) were identified } \\
\text { in } 18 \mathrm{~S} \text {. Indiana and } 17 \mathrm{~S} \text {. California isolates. }\end{array}$ \\
\hline
\end{tabular}


Table 3 Epidemiology of oqxAB in Klebsiella pneumoniae

\begin{tabular}{|c|c|c|c|c|c|c|c|}
\hline References & $\begin{array}{l}\text { Bacterial } \\
\text { species }\end{array}$ & $\begin{array}{l}\text { Year(s) of } \\
\text { isolates } \\
\text { collection }\end{array}$ & Geographic area & $\begin{array}{l}\text { Sample } \\
\text { source }\end{array}$ & $\begin{array}{l}\text { Percentage of } \\
\text { oq } \times A B \text { carring } \\
\text { isolates } \\
\text { (no. of isolates) }\end{array}$ & $\begin{array}{l}\text { Resistance } \\
\text { phenotype(s) }\end{array}$ & Descriptions \\
\hline [19] & $\begin{array}{l}\text { K. } \\
\text { pneumoniae }\end{array}$ & $\begin{array}{l}1998- \\
2006\end{array}$ & Seoul Korea & Human & $\begin{array}{l}\text { K. pneumoniae: } \\
74.1 \% \\
(100 / 135)\end{array}$ & OLA, CIP & $\begin{array}{l}\text { This is the first report of the presence of an } \\
\text { oqxAB-containing plasmid in a human isolate } \\
\text { of } E \text {. coli. }\end{array}$ \\
\hline [14] & $\begin{array}{l}\text { K. } \\
\text { pneumoniae } \\
\text { Klebsiella } \\
\text { spp. }\end{array}$ & 2010 & Shanghai China & Human & $\begin{array}{l}\text { K. pneumoniae: } \\
100 \% \\
(154 / 154)\end{array}$ & $\begin{array}{l}\text { NAL, CIP, } \\
\text { NOR, LVX, } \\
\text { OLA, TMP, } \\
\text { CHL, TET }\end{array}$ & $\begin{array}{l}\text { Variants of oqxA2, oqxB2 and } o q \times B 3 \text { were } \\
\text { identified. }\end{array}$ \\
\hline [67] & $\begin{array}{l}\text { K. } \\
\text { pneumoniae }\end{array}$ & $\begin{array}{l}2005- \\
2010\end{array}$ & Seoul, Korea & Human & $\begin{array}{l}\text { K. pneumoniae: } \\
\text { 10.8\% (11/102) }\end{array}$ & $\begin{array}{l}\text { NAL, LVX, } \\
\text { AK, GEN, } \\
\text { TOB }\end{array}$ & $\begin{array}{l}\text { The oqxAB gene was only found in } K \text {. } \\
\text { pneumoniae isolates. }\end{array}$ \\
\hline [71] & $\begin{array}{l}\text { K. } \\
\text { pneumoniae, }\end{array}$ & 2010 & Tunis & Human & $\begin{array}{l}\text { K. pneumoniae: } \\
65 \%(26 / 40)\end{array}$ & $\begin{array}{l}\text { GEN, TOB, } \\
\text { AK, NAL, } \\
\text { CIP, SXT }\end{array}$ & $\begin{array}{l}\text { The prevalence of PMQR determinants } \\
\text { among ESBL-producing strains }\end{array}$ \\
\hline [8] & $\begin{array}{l}\text { K. } \\
\text { pneumoniae }\end{array}$ & 2012 & Northeast Ohio & Human & $\begin{array}{l}\text { K. pneumoniae: } \\
100 \%(36 / 36)\end{array}$ & CIP & $\begin{array}{l}\text { KPC-2 and KPC-3 types } \beta \text {-lactamase } \\
\text { (bla) genes }\end{array}$ \\
\hline [8] & $\begin{array}{l}\text { K. } \\
\text { pneumoniae }\end{array}$ & $\begin{array}{l}2006- \\
2009\end{array}$ & $\begin{array}{l}\text { New York, New } \\
\text { Jersey, } \\
\text { Pennsylvania }\end{array}$ & Human & $\begin{array}{l}\text { K. pneumoniae: } \\
83.3 \%(5 / 6)\end{array}$ & CIP & $\begin{array}{l}\text { KPC-2 and KPC-3 types } \beta \text {-lactamase } \\
\text { (bla) genes }\end{array}$ \\
\hline [8] & $\begin{array}{l}\text { K. } \\
\text { pneumoniae }\end{array}$ & $\begin{array}{l}1996- \\
1997\end{array}$ & $\begin{array}{l}\text { Taiwan, Turkey, } \\
\text { Australia, South } \\
\text { Africa, Argentina, } \\
\text { Belgium, the US }\end{array}$ & Human & $\begin{array}{l}\text { K. pneumoniae: } \\
87.5 \%(14 / 16)\end{array}$ & - & $\begin{array}{l}\text { TEM-10, SHV-2, SHV-5, CTX-M-2, CTX-M-3 } \\
\text { types } \beta \text {-lactamase (bla) genes }\end{array}$ \\
\hline [68] & $\begin{array}{l}\text { K. } \\
\text { pneumoniae }\end{array}$ & $\begin{array}{l}2012- \\
2014\end{array}$ & Jiangsu, China & Human & $\begin{array}{l}\text { K. pneumoniae: } \\
67.6 \%(50 / 74)\end{array}$ & $A K, Q$ & 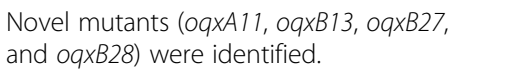 \\
\hline [69] & $\begin{array}{l}\text { K. } \\
\text { pneumoniae }\end{array}$ & $\begin{array}{l}2014- \\
2015\end{array}$ & Tehran, Iran & Human & $\begin{array}{l}\text { oqxA: } 56.7 \% \\
(140 / 247) \\
\text { oqxB: } 54.6 \% \\
(135 / 247)\end{array}$ & $\begin{array}{l}\text { CAZ, NOR, } \\
\text { CTX, CPD, } \\
\text { NAL, CIP, } \\
\text { GEN, TGC,AK }\end{array}$ & 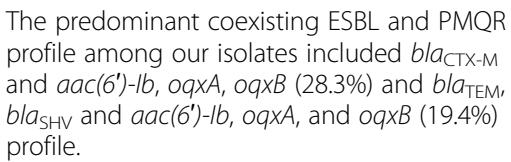 \\
\hline
\end{tabular}

Notes: OLA olaquindox, CHL chloramphenicol, CIP ciprofloxacin, TET tetracycline, SXT sulfamethoxazole-trimethoprim, LVX levofloxacin, CTX cefotaxime, CAZ ceftazidime, GEN gentamicin, CTX cefotaxime, $A K$ amikacin, TOB tobramycin, NAL nalidixic acid, CPD cefpodoxime, TGC tigecycline, $Q$ quinolones

Klebsiella pneumonia chromosome

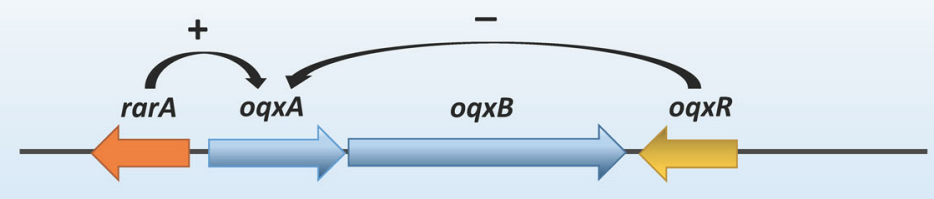

Escherichia coli plasmid pOLA52

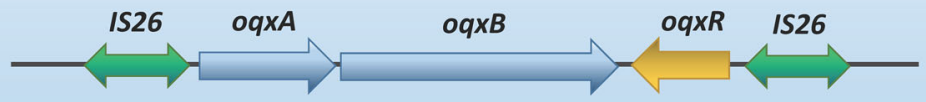

Fig. 1 Genomic organization of the rarA-oqXABR locus on the chromosome of Klebsiella pneumoniae and IS26- oqXABR transposon on the plasmid of pOLA52 in Escherichia coli 

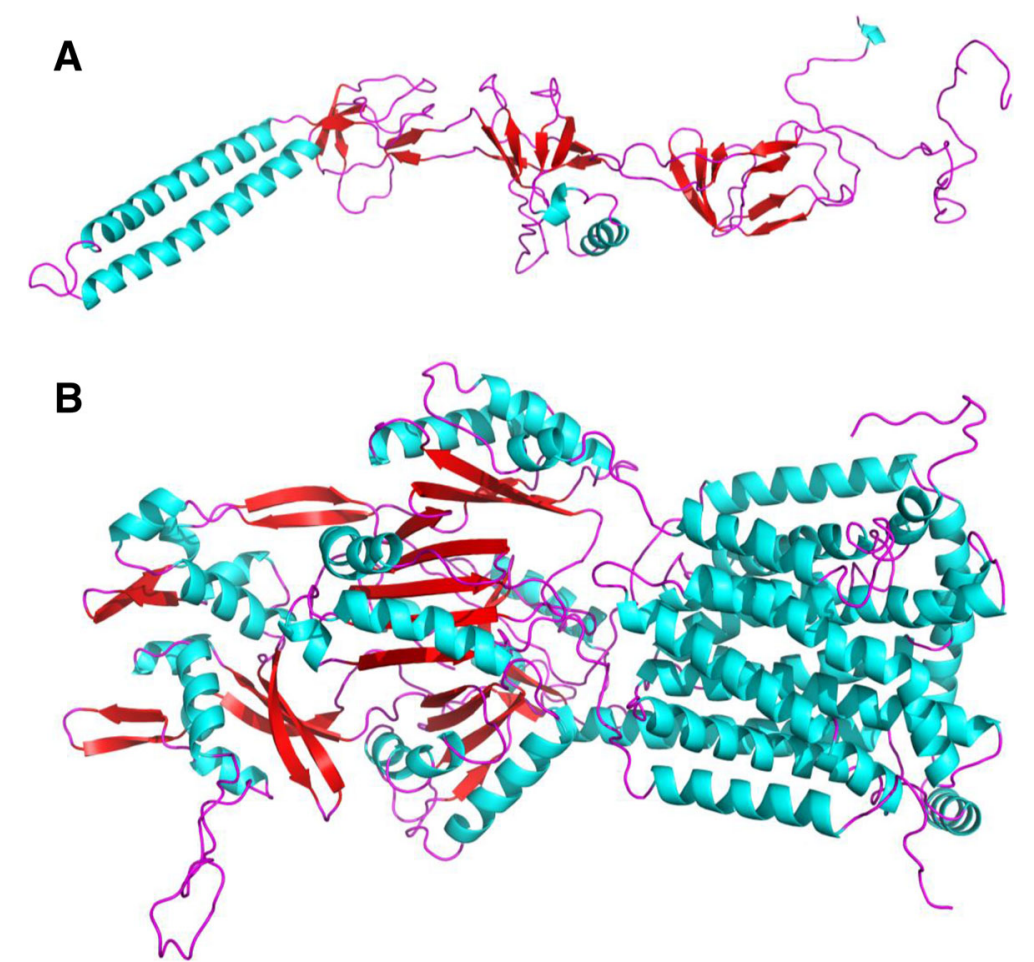

Fig. 2 The structures of $\operatorname{OqXA}(\mathbf{a})$ and $\operatorname{OqxB}(\mathbf{b})$ protein predicted by homology modeling using SYBYL X-2.0

In $K$. pneumoniae, the regulatory mechanisms of OqxAB efflux pump have been extensively studied. In 2012, a novel chromosomally encoded AraC-type positive regulator (RarA, regulator of antibiotic resistance A) was identified from K. pneumoniae. Overexpression of $\operatorname{rar} A$ can upregulate expression levels of its downstream efflux pump operon $o q x A B$ and $a c r A B$ [22]. The rarA gene was located on the genomes of several $E n$ terobacteriaceae, such as K. pneumoniae, Enterobacter and Serratia proteamaculans. Plasmid-mediated overexpression of rarA can lead to MDR phenotype in either $E$. coli or $K$. pneumoniae without the presence of rob, marA or soxS, but requires the assistance of a functional AcrAB efflux pump. A transcriptome and phenotypic microarray study showed that rarA in K. pneumoniae may be associated with the functions of cell envelope biogenesis and posttranslational modification, transport proteins and the porin OmpF, and thus enhanced growth of the over expresser under the pressure of several antibiotic classes, i.e., minocycline, beta-lactams, polymyxin B, fluoroquinolones (FQs), furaltadone and sanguinarine [23]. Jiménez-Castellanos et al. confirmed that the OqxAB was regulated by RamA and RarA, while AcrAB efflux pump was regulated by RamA and SoxS, and the outer membrane protein TolC was controlled by all these regulators in $K$. pneumoniae [24]. RamA is the most effective transcriptional regulator of antibiotic susceptibility in K. pneumoniae, followed by RarA, SoxS, and MarA.
Another GntR-type regulator, $o q x R$, was generally located neighboring to the $o q x A B$ and could decrease the expression of the OqxAB efflux pump. Several amino acid substitutions including Phe6Ser, Gln11Leu, Asp95Glu, Val113Ile, and frameshift deletion of amino acids 73 to 77 or positions 88 to 94 , have been identified on the OqxR and may be detrimental to its function [22]. A novel amino acid substitution (Val102Gly) identified on the OqxR in a clinical isolate of $K$. pneumoniae could also induced the elevated expression of both $o q x A B$ and $\operatorname{rar} A$ [25]. Complementation with wild-type $o q x R$ can restore the susceptibility to antibiotics and normalized the $\operatorname{rar} A$ and $o q x A B$ expression levels. Overactivation of the OqxAB efflux pump contributed to the MDR phenotype and enhanced virulence of this particular clinical isolate [25]. Taken together, $o q x A B$ is subject to regulation by both RarA and RamA (AraC-type transcriptional activator) and OqxR (GntR-type transcriptional repressor).

The overexpression of oq $x A B$ was found to confer more than 4 -fold reduced susceptibility to a variety of antibiotics, including quinoxaline compounds (olaquindox and carbadox), chloramphenicol, quinolones and fluoroquinolones, and trimethoprim. Besides, the OqxAB multidrug efflux pump also contributed to the reduced susceptibility to detergents and disinfectants, including benzalkonium chloride, triclosan, especially SDS [26]. The oq $x A B$ bearing plasmid pOLA52 could readily be transferred among Enterobacteriaceae and the transconjugants showed reduced 
susceptibility to chloramphenicol, ciprofloxacin and olaquindox [26]. The MDR phenotypes were attributed to the overexpression of the $\operatorname{oq} x A B$, as illustrated by the gene expression analysis. Transposition of oqxAB gene from chromosome to plasmids was able to result in more than 80-fold increase of the OqxAB efflux pump expression level, thus leading to the MDR phenotypes [13]. Over the past decades, there have been increasing studies reporting the magnitudes of the OqxAB efflux pump's contribution to reduced susceptibility to different classes of drugs, and the prevalence of $o q x A B$ gene complex in various bacteria originated from human and animal sources (Tables 1, 2 and 3).

\section{Relationship of OqxAB efflux pump with quinoxaline resistance}

OqxAB efflux pump has been the only known resistance genetic mechanism against quinoxalines till now. The quinoxaline representative drug olaquindox is generally used as a growth promoter on piglets at concentration up to $100 \mathrm{mg} / \mathrm{kg}$ per feed [9]. In European countries, the application of olaquindox was banned in 1999 due to its potential toxicity [27]. Furthermore, there have been serious concerns due to the possibility for selection of drug resistance since its introduction in the 1980s. An epidemiological study from Denmark in 1999 has demonstrated the presence of olaquindox resistant bacteria [9]. Other studies also reported that the increase of olaquindox resistance increased along with the usage of olaquindox as growth promoter in the pig farms $[28,29]$.

The oqxA gene was detected in olaquindox resistant E. coli collected from Danmark and Sweden from 1995 to 1998 [27]. In an epidemiological study from China, of all the 172 strains of $E$. coli, the $o q x A B$ gene was detected in $46.3 \%$ of the isolates from swine, $13 \%$ from chicken, $43.9 \%$ from farm environment and $30.3 \%$ from farmworkers [17]. In comparision to the oqxAB-negative isolates, the $\mathrm{MIC}_{50}$ values of quinoxalines (mequindox and olaquindox) were 8- to 32 -fold higher in the $o q x A B$-positive isolates [17]. In a recent study, the $o q x A B$ prevalence among animals isolates (33.39\%) was much higher than food (17.34\%) and human (18.07\%) isolates [30]. Another study from Henan province in China showed that $\operatorname{oqx} A B$ were observed in $58.5 \%(62 / 106)$ of the $E$. coli isolates from dogs, $56.25 \%$ (36/64) from cats, and $42.0 \%(42 / 100)$ from human patients [31]. The $\mathrm{MIC}_{50}$ values of olaquindox against $o q x A B$-positive isolates were 4- to 16-fold higher than those of the oqxAB-negative isolates [31]. These studies demonstrated that the OqxAB multidrug efflux pump significantly contributed to the reduced susceptibility or resistance to olaquindox.

The $o q x A B$ was also reported to be responsible for the reduced susceptibility to another quinoxaline drug mequindox in E. coli. Of all the 1123 strains of enteropathogenic
Escherichia coli (EPEC) isolated from farm animals in China from 1970s to 2013, oqxAB gene cassete was detected in $94.4 \%$ (322/341) of the high-level resistant strains $\left(\mathrm{MIC}_{\mathrm{MEQ}} \geq 64 \mathrm{mg} / \mathrm{L}\right)$ and $1.2 \%(9 / 782)$ of the low-level resistant isolates with mequindox $\mathrm{MICs} \leq 32 \mathrm{mg} / \mathrm{L}$ [32]. In addition, the circular intermediate of IS26-oq $x A B$ was deteced in $93.4 \%$ of the oq $x A B$-positive strains, suggesting that the $o q x A B$-carring transposon Tn6010 was unstable and tend to excision through the IS26-mediated recombination [32].

\section{Contribution of OqxAB efflux pump to quinolone resistance}

Most of the studies regarding $o q x A B$ have focused on the contribution of OqxAB efflux pump to the quinolone resistance, since quinolone and FQs antibiotics are one of the most critically important classes of broad spectrum anti-infective agents which are used to treat various bacterial infections in both humans and animals [33]. The mechanisms of quinolone resistance mainly consists of target-site gene mutations that lead to amino acid substitutions in the quinolone resistance-determining regions (QRDRs) of the topoisomerase unit, reduced intracellular drug accumulation by overexpression of multidrug efflux pumps or decreased permeability of outer membrane porins, and plasmid-mediated quinolone resistance mechanisms [34].

The $o q x A B$ has been recognized as one of the four genetic mechanisms of the PMQRs in recent years and there is a lot of data with regard to its contribution to the FQ resistance phenotype (Tables 1, 2 and 3). As demonstrated by RT-PCR, the expression levels of oq $x A B$ in ESBL-producing $K$. pneumoniae with reduced susceptibility to quinolones were 4-fold higher than the susceptible strains [35]. Knocking out the oqxAB-encoding plasmid using homologous recombination in a FQ-resistant clinical E. coli strain with no mutations on the QRDRs of DNA gyrase and topoisomerase IV could decrease FQ MICs by 2- or 4-fold, and the OqxAB efflux pump may also work in conjuction with TolC to mediating the decreased FQ resistance [36]. Wong et al. cloned oq $x A B$ gene into a plasmid ( $\mathrm{pTrc}$ ) and transformed into Salmonella typhimurium strain LT2, and found that acquisition of the oqxAB-encoding plasmid by other two $S$. typhimurium isolates (strain 11-28 and strain 10-63) caused a 4-fold increase of MIC to ciprofloxacin and also conferred resistance to streptomycin, ampicillin, tetracycline, chloramphenicol, trimethoprim, sulfamethoxazole, nalidixic acid and olaquindox [37].

The OqxAB efflux pump could not only mediate low-level quinolone resistance, but also is important for the bacteria to survive under low concentration of FQs and facilitate the subsequent topoisomerase mutations associated with higher level resistance [38]. In 
comparison to the Qnr-producing isolates, the frequencies of topoisomerase mutations in $o q x A B$ - and qepA-carring strains were relatively higher [39]. A recent study showed that acquisition of oqxAB-carring plasmids by $E$. coli led to a 4-8 fold increase in the MIC and a 8-16 fold elevation of the mutation prevention concentration (MPC) to ciprofloxacin. Meanwhile, the development of FQ resistance was faster in the transformants bearing the oqxAB-carring plasmids than that in the parental strain, particularly before 16 passages [40]. The oqxAB-carring plasmid in E.coli induced a fitness cost in vitro, however, the biological benefits were observed in vivo and their fitness was increased when combined with chromosomal mutations [40]. However, the growth of oqxAB-bearing Salmonella was much weaker than the parent strain, indicating the fitness cost of acquisition of oq $x A B$ in Salmonella [37].

The oqxAB gene has been frequently detected in quinolone resistant bacteria, such as E. coli (Table 1), Salmonella (Table 2) and K. pneumoniae (Table 3). The prevalence of $o q x A B$ in $E$. coli of human origin was firstly reported in 2009 and relatively lower than that of the animal or environmental sources [19]. The oqxAB genes were $1(0.4 \%)$ of 261 strains of E. coli, $3(4.6 \%)$ of 65 strains of Enterobacter cloacae, and 100 (74.1\%) of 135 strains of K. pneumoniae recovered from blood samples collected from patients in Seoul National University Hospital from 1998 to 2006 [19]. Two novel mutants of $o q \times B$ (oqxB20 and oqxB29) were also identified E.coli in China [41]. The first detection of oqxAB-carring $E$. coli in Latin America was in 2017 from Bolivia [42]. The $o q x A B(n=15)$ and $a a c\left(6^{\prime}\right)-I b-c r(n=14)$ were the most prevalent PMQR genes in 248 strains of levofloxacin resistant E. coli collected from a university hospital in Taiwan from 2001 to 2015 [43]. Of 190 strains of E. coli collected from a rural and a urban hospital wastewaters in India, two isolates were found to be oqxAB-positive, emphasizing the importance to dispose the wastewater properly to reduce the pollution of environment with resistance genes and resistant bacteria [44].

In comparison to the low prevalence of $o q x A B$ in $E$. coli of human origin, the frequency of oqxAB in animal isolates is relatively high. The $o q x A B$ was even detected in $E$. coli isolated from ducks, geese and as early as 1994 from chickens [45]. The presence of $o q x A B$ in $E$. coli from farm and wild lagomorphs was reported in Italy in the 113 strains of multi-drug resistant $E$. coli collected from 2006 to 2008 [46]. The dissemination of oq $x A B$ located on a transferable plasmid pHXY0908 between Salmonella and E. coli in the chickens gut was observed under the treatment of chickens with enrofloxcin [47]. Several investigation data showed that in China the prevalence of $o q x A B$ was in $19-51 \%$ in swine and chicken, which was higher than the prevalence of other PMQR genes (qnr 5.7-13.6\%, aac(6')-Ib-cr 4.9$11.6 \%$ and qepA $2.6-3.64 \%$ ) in animal original strains, and much higher the prevalence of oqxAB in human strains [45, 48-50].

Many reports emphasized the co-spread of $o q x A B$ with other resistance genes, virulence genes and heavy metal resistance genes in E.coli. The sequences of several plasmids from foodborne E. coli, such as pEC012 [51], pE80 [52] and p42-2 [53] had been published in the Genebank. These conjugative plasmids harbored multiple resistance determinants, including oq $x A B, b l a_{\mathrm{CTX}-\mathrm{M}-65}, r m t B$, fos $A 3$ and $f l o R$, indicating a therapeutic challenge due to co-selection by various antibiotics and thus compromise the effectiveness of current antimicrobial strategies. In 2011, Liu et al. described co-existence of PMQR genes (oqxAB and $a a c\left(6^{\prime}\right)$ $I b-c r)$, ESBLs encoding gene $\left(b l a_{\mathrm{CTX}-\mathrm{M}-24}\right)$ and a virulence determinant iroN on the same plasmid in an E. coli strain a6 [54]. They further reported the co-dissemination of $o q \times A B, b l a_{\text {CTX-M }}$ and floR on the similar plasmids (F33:A-: B- and HI2) [16] and $o q x A B, b l a_{\mathrm{DHA}-1}$, and 16S rRNA methylase gene $r m t B$ on the same plasmid JGDA2 [55]. In E. coli isolated from pigeon farms in China in 2011-2012, the PMQRs (oqxAB and aac(6')-Ib-cr), CTX-M type ESBLs encoding genes (CTX-M-65, CTX-M-27 and CTXM-55) and $r m t B$ were found to be co-transferred by IncF plasmid alone or in combination with the IncK [56]. The co-existence of oqxAB, bla $a_{\mathrm{CTX}-\mathrm{M}}$ and other antibiotic resistance genes with the pco and sil operons, which contributed to the increase of the MICs to $\mathrm{CuSO}_{4}$ and $\mathrm{AgNO}_{3}$ on IncHI2 plasmids, were also observed [57]. The co-existence of antibiotic resistance genes and heavy metal resistance genes might promote the development of multidrug resistant bacteria when exposed to heavy metals, particularly copper and zinc, which were commonly used as growth promoters for some livestock species.

The first report of $o q x A B$ presence in Salmonella was in 2012 and the $o q x A B$ gene associated with IS26 was located on the chromosome of two strains of Salmonella Derby isolated from pork samples in Hong Kong [58]. The $o q x A B$ gene was detected in $112(72.73 \%)$ of 154 strains of $S$. enterica serovar Indiana recovered from animals $(n=133)$ and humans $(n=21)$ in China from 2009 to 2013 and showed concurrent resistance to both ciprofloxacin and cefotaxime [59]. The 12 (2\%) of 546 strains of human clinical Salmonella Typhimurium collected from patients in China from 2005 to 2011 were co-resistant to both ciprofloxacin and ceftriaxone, four of the 12 resistant isolates carried $o q x A B$ gene and a single gyrA (D87N) mutation [60]. The oqxAB (42.0\%) was found in 462 strains of FQ-resistant Salmonella collected from retail chicken meat in China during 2010-2011 [61]. The prevalence of oqxAB was $16.1 \%$ in the 76 strains of cephalosporins resistant and quinolones resistant Salmonella identified from 1416 clinical isolates in 
Taiwan from 1999 to 2008 [62]. Among 82 Salmonella collected from food in Shenzhen of China from October 2012 to June 2013, which showed co-resistance to three critically important antibiotics (ceftriaxone, 10\%; ciprofloxacin, 39\%; azithromycin, 25\%), the oqxAB (91\%), $a a c\left(6^{\prime}\right)-I b-c r(75 \%)$ and $q n r S(66 \%)$ were frequently detected [63]. The combination of $o q x A B$ and a single target mutation on GyrA could possibly mediate development of resistance to ciprofloxacin in Salmonella, and dramatically reduced the time required for the development of a resistance associated with generation of double GyrA mutations and single ParC mutation [63].

In Salmoenlla, the $\operatorname{oq} x A B$ was also found to be co-spread with other resistance genes. In 2013, Li et al. reported that the $a a c\left(6^{\prime}\right)-I b-c r(36.5 \%), o q x A B(31.7 \%)$ and qnrS1 (1.6\%) were present alone or in combination in 63 strains of $S$. Typhimurium isolates collected from animals in China and the $o q x A B$ and $a a c\left(6^{\prime}\right)-I b-c r$ genes were found to be located on the same IncHI2-type plasmids [15]. Of 170 strains of Salmonella isolates recovered from 1540 chicken samples in China from 2015 to 2016, the resistance rates of ciprofloxacin, amikacin and cefotaxime were as high as $68.2,48.2$ and $44.7 \%$, respectively and oqxAB (8.24\%) and $a a c\left(6^{\prime}\right)-I b-c r(15.88 \%)$ were the most prevalent PMQR genes [64]. Recently, the co-spread of $o q x A B$ and $m c r-1$, which conferred resistance to colistin, were also found on a transferable IncI2 plasmid in $S$. Typhimurium /ST34 [65].

The wide distribution of $o q x A B$ was found among the clinical isolates of MDR $K$. pneumoniae, which is a frequent nosocomial pathogen and causes life-threatening disease in humans [66]. In an international report of ESBL-producing $K$. pneumoniae, the $o q x A B$ gene was detected in $87.5 \%(14 / 16)$ of the isolates collected from Hospitals in Taiwan, Australia, Argentina, Belgium, Turkey, South Africa, and the United States from 1996 to 1997 [8]. For K. pneumoniae isolates collected from the mid-Atlantic, oqxAB was observed in $71 \%(22 / 31)$ of the ST 258 isolates and $91.7 \%$ (11/12) of the non-ST 258 isolates, respectively. The $o q x A B$ was $100 \%$ detected among both quinolone resistant and quinolone-susceptible KPCproducing $K$. pneumoniae recovered from northeast Ohio [8]. An epidemiology study from China reported that $66.9 \%$ of the $K$. pneumoniae were resistant to ciprofloxacin and the oq $x A B$ gene was detected in all the $K$. pneumoniae isolates [14]. Of 22 nonduplicate strains of ciprofloxacin-nonsusceptible $K$. pneumoniae $(n=22)$ recovered from blood samples of patients at a tertiary hospital in Korea from 2005 to 2010, oqxAB was detected in 11 (50\%) strains of $K$. pneumoniae [67]. Of 74 carbapenemase-producing $K$. pneumoniae collected from a tertiary hospital in China from 2012 to 2014, oqxAB was detected in $48 \mathrm{FQ}$-resistant and 2 FQ-susceptible K. pneumoniae isolates and Variants of $o q \times A 11, o q \times B 13, o q \times B 27$ and $o q \times B 28$ were identified
[68]. In the 247 strains of ESBLs-producing K. pneumoniae from 750 patients with nosocomial urinary tract infection (UTI), $o q x A$ and $o q x B$ were 56.7 and $54.6 \%$ of these isolates [69]. Among the 40 strains of ciprofloxacin resistant $E$. coli and 50 strains of ciprofloxacin resistant ESBLs-producing Klebsiella spp. isolated from blood samples in Hungary, the $o q x A$ and $o q x B$ were 48 and $40 \%$ of the isolates, respectively [70]. Among the 32 strains of $K$. pneumoniae from Tunisian hospital, oq $x A B$ was observed in $65 \%$ of the $K$. pneumoniae [71]. OqxAB was detected on the chromosome of a hypermucoviscous, multidrug resistant, biofilm producing $K$. pneumoniae strain U25 from India, as demonstrated by whole genome sequencing [72]. $O q x A B$ was also detected on the plasmid of IncR with other resistance genes like $b l a_{\mathrm{NDM}-1}$ in two carbapenem resistant $K$. pneumoniae isolates collected from urine samples in a patient hospitalized at Annaba University hospital (Algeria) in 2014 [73].

\section{Role of OqxAB efflux pump in tigecycline resistance}

Tigecycline is one of the few effective therapeutic options for treating serious infections caused by MDR pathogens, such as K. pneumoniae [74]. Resistance mechanisms of tigecycline have been comprehensively studied. Overexpression of multidrug efflux pumps such as AcrAB in $E$. coli [75], K. pneumoniae [74], and Enterobacter cloacae [76]; AdeABC in Acinetobacter baumanni [77], and MexXY in Pseudomonas aeruginosa [78] have been implicated to contribute to tigecycline resistance. For K. pneumoniae isolates with MICs no more than $8 \mathrm{mg} / \mathrm{ml}$, AcrAB-TolC efflux pump played the most important role in the tigecycline resistant $K$. pneumoniae, while for strains with $\mathrm{MICs} \geq 16 \mathrm{mg} / \mathrm{ml}$, both AcrAB-TolC and OqxAB efflux pumps are required [74]. OqxAB efflux pump was also associated with the heteroresistance to tigecycline in Salmonella, which was attributed to the overexpression of AcrAB-TolC and OqxAB efflux pumps, since $\mathrm{PA} \beta \mathrm{b}$ restored the susceptibility to tigecycline in heteroresistant isolates and accumulation of tigecycline in cell was also reduced [79]. Veleba and Schneiders verified the important roles of $\operatorname{ram} A$ and $\operatorname{rar} A$ on the overexpression of efflux pump encoding genes $a c r A B$ and $o q x A B$, and its contribution to the tigecycline resistance in $K$. pneumoniae, Enterobacter cloacae and Enterobacter aerogenes $[22,80]$. Higher transcription levels of rarA in conjunction with $\operatorname{qq}_{x B}$ were also observed in tigecycline resistant $K$. pneumoniae isolates in comparison with a tigecycline-susceptible strain [74]. By studying five isogenic paired clinical isolates of $K$. pneumoniae identified from same patient in a medical center in Taiwan, the researchers found that acquisition of tigecycline resistance in K. pneumoniae did not necessarily compromise their virulence and growth [81]. They further reported that bacteremia, 
caused by infection with tigecycline-nonsusceptible $K$. pneumoniae was linked to high mortality, and previous medication of fluoroquinolones was the independent risk factor for the selection of tigecycline resistance in K. pneumoniae [82].

\section{Role of OqxAB efflux pump in nitrofurantoin resistance}

Nitrofurantoin is a valuable antibiotic used to treat acute uncomplicated urinary tract infections [83]. Resistance to nitrofurantoin in $E$. coli was primarily due to mutations in the nitroreductase genes ( $n f_{S} A$ and $n f_{S} B$ ), which participated in the converting of antibiotics into toxic intermediate compounds [84]. Recently, plasmid-mediated $o q x A B$ has been reported to be an important mechanism for nitrofurantoin (NIT) resistance [85]. Ho et al. investigated the molecular epidemiology of $o q x A$ and $o q x B$ and its relationships with nitrofurantoin resistance in 341 strains of $E$. coli, which were recovered from patients suffered from UTI $(n=205$; collected in 2004 to 2013) and animals ( $n=136$; collected in 2012 to 2013) [85]. They found that the prevalence of $o q x A B$ gene was significantly higher in the NIT-intermediate (11.545.5\%) and NIT-resistant (39.2-65.5\%) isolates than that in the NIT-susceptible strain $(0-1.7 \%)$. In the 20 NIT-intermediate/resistant $E$. coli isolates, curing of the oq $x A B$-bearing plasmids could lead to the reduction of geometric mean $\mathrm{MIC}_{(\mathrm{NIT})}$ from $168.9 \mathrm{~g} / \mathrm{ml}$ to $34.3 \mathrm{~g} / \mathrm{ml}$. Acquisition of the plasmid-borne $o q x A B$ could result in a 2 to 16 fold elevation of the $\mathrm{MIC}_{(\mathrm{NIT})}$ and increase the mutation prevention concentration of NIT from $128 \mathrm{~g} / \mathrm{ml}$ to $256 \mathrm{~g} / \mathrm{ml}$. The combination of $o q x A B$ and $n f s A$ (chromosomal nitroreductase gene) mutations was sufficient to confer clinically important high-level NIT resistance in E. coli [85].

\section{Conclusions}

Since the discovery of $o q x A B$ in 2003, the gene has been reported to locate on different plasmids with other antimicrobial resistance genes and virulence determinants in various bacteria, especially in E. coli, Salmonella and Enterobacter aerogenes. The plasmid-borne $o q x A B$ was most likely to be originated from the chromosome of $K$. pneumoniae. The OqxAB efflux pump significantly contributed to reduced susceptibility to olaquindox, tigecycline, nitrofurantoin and chloramphenicol, and facilitated the development of highlevel fluoroquinolone resistance. There is a great need to monitor the potential dissemination of the $\operatorname{oq} x A B$ gene among humans, animals and environment. Further investigation and understanding of the natural functions, determinants of mobilization, and the regulation of expression of the OqxAB efflux pump will aid in future strategies of antimicrobial usage optimization.

\section{Abbreviations}

AMP: Ampicillin; CBX: Carbadox; CHL: Chloramphenicol; E. coli: Escherichia coli; EPEC: Enteropathogenic Escherichia coli; FQs: fluoroquinolones; $K$. pneumoniae: Klebsiella pneumoniae; KAN: Kanamycin; MDR: Multidrug resistance; MIC: Minimal inhibitory concentration; $\mathrm{MIC}_{50}$ : Minimum inhibitory concentration of the antibiotic for inhibiting $50 \%$ of the isolates; MPC: Mutation prevention concentration; NIT: Nitrofurantoin; OLA: Olaquindox; PMQR: Plasmid-mediated quinolone resistance; QRDRs: Quinolone resistance-determining regions; RND: Resistance nodulation and cell division; RT-PCR: Real time polymerase chain reaction; STR: Streptomycin; SXT: Sulfamethoxazole; TMP: Trimethoprim; UTI: Urinary tract infection

\section{Acknowledgements}

We appreciate the kind assistance of Chunbei Liu and Anxiong Huang in the preparation of the manuscript.

\section{Funding}

This review received supports from by National Key research and development program [2016YFD0501302/2017YFD0501406], National Natural Science Foundation of China [31772791], Fundamental Research Funds for the Central Universities [2662018JC001] and National Program for Risk Assessment of Quality and Safety of Livestock and Poultry Products [GJFP2019007]. However, the opinions expressed in this review are that of the authors.

\section{Availability of data and materials \\ This narrative review was based on data extracted from published papers available in the public domain.}

\section{Authors' contributions \\ $J \mathrm{~L}, \mathrm{HHH}$ and $\mathrm{ZHY}$ conceived the project, reviewed the articles and extracted the data. JL, HYZ, JNN, GYC and AS wrote the initial draft of the manuscript.} All authors revised and approved the submission of the manuscript.

Ethics approval and consent to participate

Not applicable.

Consent for publication

Not applicable.

\section{Competing interests}

The authors declare that they have no competing interests.

\section{Publisher's Note}

Springer Nature remains neutral with regard to jurisdictional claims in published maps and institutional affiliations.

\section{Author details}

${ }^{1}$ National Reference Laboratory of Veterinary Drug Residues (HZAU) and Key Laboratory of the Detection for Veterinary Drug Residues, Wuhan 430070, Hubei, China. ${ }^{2}$ Institute of Veterinary Medicine, Jiangsu Academy of Agricultural Sciences, Nanjing 210014, Jiangsu, China. ${ }^{3}$ Laboratory of Quality \& Safety Risk Assessment for Livestock and Poultry Products (Wuhan), Ministry of Agriculture, P.R China, Wuhan 430070, Hubei, China. ${ }^{4}$ College of Veterinary Sciences and Animal Husbandry, Abdul Wali Khan University Mardan, Mardan, KP, Pakistan.

Received: 27 August 2018 Accepted: 3 February 2019

Published online: 22 February 2019

\section{References}

1. Holmes AH, Moore LSP, Sundsfjord A, Steinbakk M, Regmi S, Karkey A, Guerin PJ, Piddock LJV. Understanding the mechanisms and drivers of antimicrobial resistance. Lancet. 2016;387:176-87.

2. Sun J, Deng Z, Yan A. Bacterial multidrug efflux pumps: mechanisms, physiology and pharmacological exploitations. Biochem Biophys Res Commun. 2014;453:254-67.

3. Hernando-Amado S, Blanco P, Alcalde-Rico M, Corona F, Reales-Calderon $J A$, Sanchez MB, Martinez JL. Multidrug efflux pumps as main players in 
intrinsic and acquired resistance to antimicrobials. Drug Resist Updates. 2016:28:13-27.

4. Blair JMA, Richmond GE, Piddock LJV. Multidrug efflux pumps in gramnegative bacteria and their role in antibiotic resistance. Future Microbiol. 2014;9:1165-77.

5. Nakaminami H, Noguchi N, Sasatsu M. Fluoroquinolone efflux by the plasmid-mediated multidrug efflux pump QacB variant QacBIII in Staphylococcus aureus. Antimicrob Agents Chemother. 2010;54:4107-11.

6. Tauch A, Schluter A, Bischoff N, Goesmann A, Meyer F, Puhler A. The 79,370-bp conjugative plasmid pB4 consists of an IncP-1 beta backbone loaded with a chromate resistance transposon, the strA-strB streptomycin resistance gene pair, the oxacillinase gene Bla (NPS-1), and a tripartite antibiotic efflux system of the resistance-nodulation-division family. Mol Gen Genomics. 2003;268:570-84.

7. Hansen LH, Johannesen E, Burmolle M, Sorensen AH, Sorensen SJ. Plasmidencoded multidrug efflux pump conferring resistance to olaquindox in Escherichia coli. Antimicrob Agents Chemother. 2004;48:3332-7.

8. Perez F, Rudin SD, Marshall SH, Coakley P, Chen L, Kreiswirth BN, Rather PN, Hujer AM, Toltzis $P$, van Duin $D$, Paterson DL, Bonomo RA. OqxAB, a quinolone and olaquindox efflux pump, is widely distributed among multidrug-resistant Klebsiella pneumoniae isolates of human origin. Antimicrob Agents Chemother. 2013;57:4602-3.

9. Sorensen $A H$, Hansen $L H$, Johannesen E, Sorensen SJ. Conjugative plasmid conferring resistance to olaquindox. Antimicrob Agents Chemother. 2003; 47:798-9.

10. Burmolle M, Bahl MI, Jensen LB, Sorensen SJ, Hansen LH. Type 3 fimbriae, encoded by the conjugative plasmid pOLA52, enhance biofilm formation and transfer frequencies in Enterobacteriaceae strains. Microbiology. 2008; 154:187-95.

11. Norman A, Hansen LH, She Q, Sorensen SJ. Nucleotide sequence of POLA52: a conjugative InCX1 plasmid from Escherichia coli which enables biofilm formation and multidrug efflux. Plasmid. 2008;60:59-74.

12. Guillard T, Lebreil AL, Hansen LH, Kisserli A, Berger S, Lozniewski A, Alauzet C, de Champs C. Discrimination between native and Tn6010-associated oqxAB in Klebsiella spp., Raoultella spp., and other Enterobacteriaceae by using a two-step strategy. Antimicrob Agents Chemother. 2015;59:5838-40.

13. Wong MHY, Chan EWC, Chen S. Evolution and dissemination of OgXAB-like efflux pumps, an emerging quinolone resistance determinant among members of Enterobacteriaceae. Antimicrob Agents Chemother. 2015;59:3290-7.

14. Yuan JY, Xu XG, Guo QL, Zhao X, Ye XY, Guo Y, Wang MG. Prevalence of the oqXAB gene complex in Klebsiella pneumoniae and Escherichia coli clinical isolates. J Antimicrob Chemother. 2012;67:1655-9.

15. Li L, Liao X, Yang Y, Sun J, Li L, Liu B, Yang S, Ma J, Li X, Zhang Q, Liu Y. Spread of oqXAB in Salmonella enterica serotype typhimurium predominantly by IncHI2 plasmids. J Antimicrob Chemother. 2013;68:2263-8.

16. Liu BT, Yang QE, Li L, Sun J, Liao XP, Fang LX, Yang SS, Deng H, Liu YH. Dissemination and characterization of plasmids carrying oqXAB-bla CTX-M genes in Escherichia coli isolates from food-producing animals. PLoS One. 2013;8:e73947

17. Zhao J, Chen $Z$, Chen $S$, Deng $Y$, Liu $Y$, Tian $W$, Huang $X$, Wu C, Sun $Y$, Sun $Y$, Zeng Z, Liu JH. Prevalence and dissemination of ogXAB in Escherichia coli isolates from animals, farmworkers, and the environment. Antimicrob Agents Chemother. 2010;54:4219-24.

18. Li L, Liao XP, Liu ZZ, Huang T, Li X, Sun J, Liu BT, Zhang Q, Liu YH. Cospread of ogXAB and blaCTX-M-9G in non-Typhi Salmonella enterica isolates mediated by ST2-IncHI2 plasmids. Int J Antimicrob Agents. 2014;44:263-8.

19. Kim HB, Wang $M$, Park $C H$, Kim EC, Jacoby GA, Hooper DC. oqx AB encoding a multidrug efflux pump in human clinical isolates of Enterobacteriaceae. Antimicrob Agents Chemother. 2009;53:3582-4.

20. Wong MH, Chan EW, Xie L, Li R, Chen S. IncHI2 plasmids are the key vectors responsible for ogXAB transmission among Salmonella species. Antimicrob Agents Chemother. 2016;60:6911-5.

21. Duval V, Lister IM. MarA, SoxS and rob of Escherichia coli - global regulators of multidrug resistance, virulence and stress response. Int J Biotechnol Wellness Ind. 2013;2:101-24.

22. Veleba M, Higgins PG, Gonzalez G, Seifert H, Schneiders T. Characterization of RarA, a novel AraC family multidrug resistance regulator in Klebsiella pneumoniae. Antimicrob Agents Chemother. 2012;56:4450-8.

23. De Majumdar S, Veleba M, Finn S, Fanning S, Schneiders T. Elucidating the regulon of multidrug resistance regulator RarA in Klebsiella pneumoniae. Antimicrob Agents Chemother. 2013;57:1603-9.
24. Jimenez-Castellanos JC, Wan Ahmad Kamil WN, Cheung CH, Tobin MS, Brown J, Isaac SG, Heesom KJ, Schneiders T, Avison MB. Comparative effects of overproducing the AraC-type transcriptional regulators MarA, SoxS, RarA and RamA on antimicrobial drug susceptibility in Klebsiella pneumoniae. J Antimicrob Chemother. 2016;71:1820-5.

25. Bialek-Davenet S, Lavigne JP, Guyot K, Mayer N, Tournebize R, Brisse S, Leflon-Guibout V, Nicolas-Chanoine MH. Differential contribution of AcrAB and OqxAB efflux pumps to multidrug resistance and virulence in Klebsiella pneumoniae. J Antimicrob Chemother. 2015;70:81-8.

26. Hansen $L H$, Jensen $L B$, Sorensen $H I$, Sorensen $S$ J. Substrate specificity of the OqxAB multidrug resistance pump in Escherichia coli and selected enteric bacteria. J Antimicrob Chemother. 2007;60:145-7.

27. Hansen $L H$, Sorensen $S J$, Jorgensen HS, Jensen LB. The prevalence of the OqxAB multidrug efflux pump amongst olaquindox-resistant Escherichia coli in pigs. Microb Drug Resist. 2005;11:378-82.

28. Hedges AJ, Linton AH. Olaquindox resistance in the coliform flora of pigs and their environment: an ecological study. J Appl Bacteriol. 1988;64:429-43.

29. Linton AH, Hedges AJ, Bennett PM. Monitoring for the development of antimicrobial resistance during the use of olaquindox as a feed additive on commercial pig farms. J Appl Bacteriol. 1988;64:311-27.

30. Wang J, Guo Z-W, Zhi C-P, Yang T, Zhao J-J, Chen X-J, Zeng L, Lv L-C, Zeng $Z-L, L i u J-H$. Impact of plasmid-borne oqXAB on the development of fluoroquinolone resistance and bacterial fitness in Escherichia coli. J Antimicrob Chemother. 2017;72:1293-302.

31. Liu B, Wu H, Zhai Y, He Z, Sun H, Cai T, He D, Liu J, Wang S, Pan Y, Yuan L, $\mathrm{Hu}$ G. Prevalence and molecular characterization of oqXAB in clinical Escherichia coli isolates from companion animals and humans in Henan Province, China. Antimicrob Resist Infect Control. 2018;7:18.

32. He T, Wang $Y$, Qian $M$, Wu C. Mequindox resistance and in vitro efficacy in animal-derived Escherichia coli strains. Vet Microbiol. 2015; 177:341-6.

33. Aldred KJ, Kerns RJ, Osheroff N. Mechanism of quinolone action and resistance. Biochemistry. 2014;53:1565-74.

34. Correia S, Poeta P, Hebraud M, Capelo JL, Igrejas G. Mechanisms of quinolone action and resistance: where do we stand? J Med Microbiol. 2017;66:551-9.

35. Rodriguez-Martinez JM, Diaz de Alba P, Briales A, Machuca J, Lossa M, Fernandez-Cuenca F, Rodriguez Bano J, Martinez-Martinez L, Pascual A. Contribution of OqxAB efflux pumps to quinolone resistance in extendedspectrum-beta-lactamase-producing Klebsiella pneumoniae. J Antimicrob Chemother. 2013;68:68-73.

36. Sato T, Yokota S-I, Uchida I, Okubo T, Usui M, Kusumoto M, Akiba M, Fujii N, Tamura Y. Fluoroquinolone resistance mechanisms in an Escherichia coli isolate, HUE1, without quinolone resistance-determining region mutations. Front Microbiol. 2013;4:125.

37. Wong MH, Chan EW, Liu LZ, Chen S. PMQR genes oqXAB and aac(6')lb-cr accelerate the development of fluoroquinolone resistance in Salmonella typhimurium. Front Microbiol. 2014;5:521.

38. Piddock LV. Clinically relevant chromosomally encoded multidrug resistance efflux pumps in bacteria. Clin Microbiol Rev. 2006;19:382-402.

39. Tran JH, Jacoby GA, Hooper DC. Interaction of the plasmid-encoded quinolone resistance protein Qnr with Escherichia coli DNA gyrase. Antimicrob Agents Chemother. 2005:49:118-25.

40. Wang J, Zhi CP, Chen XJ, Guo ZW, Liu WL, Luo J, Huang XY, Zeng L, Huang JW, Xia YB, Yi MY, Huang T, Zeng ZL, Liu JH. Characterization of oqXAB in Escherichia coli isolates from animals, retail meat, and human patients in Guangzhou, China. Front Microbiol. 2017;8.

41. Zhao L, Zhang J, Zheng B, Wei Z, Shen P, Li S, Li L, Xiao Y. Molecular epidemiology and genetic diversity of fluoroquinolone-resistant Escherichia coli isolates from patients with community-onset infections in 30 Chinese county hospitals. J Clin Microbiol. 2015;53:766-70.

42. Saba Villarroel PM, Gutkind GO, Di Conza JA, Radice MA. First survey on antibiotic resistance markers in Enterobacteriaceae in Cochabamba, Bolivia. Rev Argent Microbiol. 2017:49:50-4.

43. Kao C-Y, Wu H-M, Lin W-H, Tseng C-C, Yan J-J, Wang M-C, Teng C-H, Wu J-J, Plasmid-mediated quinolone resistance determinants in quinolone-resistant Escherichia coli isolated from patients with bacteremia in a university hospital in Taiwan, 2001-2015. Sci Rep. 2016;6:32281.

44. Chandran SP, Diwan V, Tamhankar AJ, Joseph BV, Rosales-Klintz S, Mundayoor S, Lundborg CS, Macaden R. Detection of carbapenem resistance genes and cephalosporin, and quinolone resistance genes along 
with oqXAB gene in Escherichia coli in hospital wastewater: a matter of concern. J Appl Microbiol. 2014;117:984-95.

45. Chen X, Zhang W, Pan W, Yin J, Pan Z, Gao S, Jiao X. Prevalence of qnr, aac (6')Ib-cr, gepA, and oqXAB in Escherichia coli isolates from humans, animals, and the environment. Antimicrob Agents Chemother. 2012;56:3423-7.

46. Dotto G, Giacomelli M, Grilli G, Ferrazzi V, Carattoli A, Fortini D, Piccirillo A. High prevalence of oqXAB in Escherichia coli isolates from domestic and wild lagomorphs in Italy. Microb Drug Resist (Larchmont, N Y). 2014;20:118-23.

47. Chen Y, Sun J, Liao X-P, Shao Y, Li L, Fang L-X, Liu Y-H. Impact of enrofloxacin and florfenicol therapy on the spread of OqXAB gene and intestinal microbiota in chickens. Vet Microbiol. 2016;192:1-9.

48. Yang T, Zeng Z, Rao L, Chen X, He D, Lv L, Wang J, Zeng L, Feng M, Liu J-H. The association between occurrence of plasmid-mediated quinolone resistance and ciprofloxacin resistance in Escherichia coli isolates of different origins. Vet Microbiol. 2014;170:89-96.

49. Liu BT, Liao XP, Yang SS, Wang XM, Li LL, Sun J, Yang YR, Fang LX, Li L, Zhao $\mathrm{DH}$, Liu YH. Detection of mutations in the gyrA and parC genes in Escherichia coli isolates carrying plasmid-mediated quinolone resistance genes from diseased food-producing animals. J Med Microbiol. 2012;61:1591-9.

50. Xu X, Cui S, Zhang F, Luo Y, Gu Y, Yang B, Li F, Chen Q, Zhou G, Wang Y, Pang $L$, Lin L. Prevalence and characterization of cefotaxime and ciprofloxacin coresistant Escherichia coli isolates in retail chicken carcasses and ground pork, China. Microb Drug Resist (Larchmont, N Y). 2014;20:73-81.

51. Pan Y-S, Zong Z-Y, Yuan L, Du X-D, Huang H, Zhong X-H, Hu G-Z. Complete sequence of pEC012, a multidrug-resistant Incl1 ST71 plasmid carrying bla CTX-M-65, rmtB, fosA3, floR, and oqXAB in an avian Escherichia coli ST117 strain. Front Microbiol. 2016;7:1117.

52. Wong MH, Xie M, Xie L, Lin D, Li R, Zhou Y, Chan EW, Chen S. Complete sequence of a F33:A-:B- conjugative plasmid carrying the oqXAB, fos $A 3$, and blaCTX-M-55 elements from a foodborne Escherichia coli strain. Front Microbiol. 2016;7:1729.

53. Yang $Q E$, Walsh TR, Liu BT, Zou MT, Deng H, Fang LX, Liao XP, Sun J, Liu YH. Complete sequence of the Fll Plasmid p42-2, carrying blaCTX-M-55, oqXAB, fosA3, and floR from Escherichia coli. Antimicrob Agents Chemother. 2016;60: 4336-8.

54. Liu B-T, Wang X-M, Liao X-P, Sun J, Zhu H-Q, Chen X-Y, Liu Y-H. Plasmidmediated quinolone resistance determinants oqXAB and $a a c\left(6^{\prime}\right)-1 b-c r$ and extended-spectrum beta-lactamase gene blaCTX-M-24 co-located on the same plasmid in one Escherichia coli strain from China. J Antimicrob Chemother. 2011;66:1638-9.

55. Liu BT, Liao XP, Yue L, Chen XY, Li L, Yang SS, Sun J, Zhang S, Liao SD, Liu $\mathrm{YH}$. Prevalence of beta-lactamase and $16 \mathrm{~S}$ rRNA methylase genes among clinical Escherichia coli isolates carrying plasmid-mediated quinolone resistance genes from animals. Microb Drug Resist. 2013;19:237-45.

56. Yang L, Yang L, Lu DH, Zhang WH, Ren SQ, Liu YH, Zeng ZL, Jiang HX. Coprevalance of PMQR and $16 S$ rRNA methylase genes in clinical Escherichia coli isolates with high diversity of CTX-M from diseased farmed pigeons. Vet Microbiol. 2015;178:238-45

57. Fang L, Li X, Li L, Li S, Liao X, Sun J, Liu Y. Co-spread of metal and antibiotic resistance within ST3-IncHI2 plasmids from E. coli isolates of food-producing animals. Sci Rep. 2016;6:25312.

58. Wong $\mathrm{MH}$, Chen S. First detection of oqXAB in Salmonella spp. isolated from food. Antimicrob Agents Chemother. 2013;57:658-60.

59. Bai L, Zhao J, Gan X, Wang J, Zhang X, Cui S, Xia S, Hu Y, Yan S, Wang J, Li $F$, Fanning $S, X u J$. Emergence and diversity of Salmonella enterica serovar Indiana isolates with concurrent resistance to ciprofloxacin and cefotaxime from patients and food-producing animals in China. Antimicrob Agents Chemother. 2016;60:3365-71.

60. Wong MH, Yan M, Chan EW, Biao K, Chen S. Emergence of clinical Salmonella enterica serovar typhimurium isolates with concurrent resistance to ciprofloxacin, ceftriaxone, and azithromycin. Antimicrob Agents Chemother. 2014:58:3752-6.

61. Zhang Z, Meng X, Wang Y, Xia X, Wang X, Xi M, Meng J, Shi X, Wang $D$, Yang B. Presence of $a n r$, aac $\left(6^{\prime}\right)-1 b$, gepA, oqXAB, and mutations in gyrase and topoisomerase in nalidixic acid-resistant Salmonella isolates recovered from retail chicken carcasses. Foodborne Pathog Dis. 2014;11: 698-705.

62. Kao CY, Chen CA, Liu YF, Wu HM, Chiou CS, Yan JJ, Wu JJ. Molecula characterization of antimicrobial susceptibility of Salmonella isolates: first identification of a plasmid carrying anrD or ogxAB in Taiwan. J Microbiol Immunol Infect. 2017;50:214-23.
63. Lin D, Chen K, Wai-Chi Chan E, Chen S. Increasing prevalence of ciprofloxacin-resistant food-borne Salmonella strains harboring multiple PMQR elements but not target gene mutations. Sci Rep. 2015;5:14754.

64. Wang Y, Zhang A, Yang Y, Lei C, Jiang W, Liu B, Shi H, Kong L, Cheng G, Zhang $X$, Yang $X$, Wang $H$. Emergence of Salmonella enterica serovar Indiana and California isolates with concurrent resistance to cefotaxime, amikacin and ciprofloxacin from chickens in China. Int J Food Microbiol. 2017;262:23-30.

65. Li XP, Fang LX, Song JQ, Xia J, Huo W, Fang JT, Liao XP, Liu YH, Feng YJ, Sun J. Clonal spread of mcr-1 in PMQRcarrying ST34 Salmonella isolates from animals in China. Sci Rep. 2016;6.

66. Cao X, Xu X, Zhang Z, Shen H, Chen J, Zhang K. Molecular characterization of clinical multidrug-resistant Klebsiella pneumoniae isolates. Ann Clin Microb Anti. 2014:13:16

67. Yang HY, Nam YS, Lee HJ. Prevalence of plasmid-mediated quinolone resistance genes among ciprofloxacin-nonsusceptible Escherichia coli and Klebsiella pneumoniae isolated from blood cultures in Korea. Can J Infect Dis Med Microbiol. 2014;25:163-9.

68. Cheng L, Cao XL, Zhang ZF, Ning MZ, Xu XJ, Zhou W, Chen JH, Zhang JH, Shen $\mathrm{H}$, Zhang K. Clonal dissemination of KPC-2 producing Klebsiella pneumoniae ST11 clone with high prevalence of oqXAB and $r m t B$ in a tertiary hospital in China: results from a 3-year period. Ann Clin Microbiol Antimicrob. 2016;15:1.

69. Goudarzi M, Azad M, Seyedjavadi SS. Prevalence of plasmid-mediated quinolone resistance determinants and OqxAB efflux pumps among extended-spectrum beta-lactamase producing Klebsiella pneumoniae isolated from patients with nosocomial urinary tract infection in Tehran, Iran. Scientifica. 2015;2015:518167.

70. Domokos J, Kristof K, Szabo D. Plasmid-mediated quinolone resistance among extended-Spectrum Beta-lactamase producing Enterobacteriaceae from bloodstream infections. Acta Microbiol Immunol Hung. 2016;63:313-23.

71. Ferjani S, Saidani M, Amine FS, Boutiba-Ben BI. Prevalence and characterization of plasmid-mediated quinolone resistance genes in extended-spectrum beta-lactamase-producing Enterobacteriaceae in a Tunisian hospital. Microb Drug Resist. 2015;21:158-66.

72. Rafiq Z, Sam N, Vaidyanathan R. Whole genome sequence of Klebsiella pneumoniae U25, a hypermucoviscous, multidrug resistant, biofilm producing isolate from India. Mem Inst Oswaldo Cruz. 2016;111:144-6.

73. Abderrahim A, Djahmi N, Pujol C, Nedjai S, Bentakouk MC, Kirane-Gacemi D, Dekhil M, Sotto A, Lavigne J-P, Pantel A. First case of NDM-1-producing Klebsiella pneumoniae in Annaba University hospital, Algeria. Microb Drug Resist (Larchmont, N Y). 2017:23:895-900.

74. Zhong $X, X u H$, Chen D, Zhou H, Hu X, Cheng G. First emergence of acrAB and oqXAB mediated tigecycline resistance in clinical isolates of Klebsiella pneumoniae pre-dating the use of tigecycline in a Chinese hospital. PLOS One. 2014:9:e115185.

75. Keeney D, Ruzin A, McAleese F, Murphy E, Bradford PA. MarA-mediated overexpression of the $A c r A B$ efflux pump results in decreased susceptibility to tigecycline in Escherichia coli. J Antimicrob Chemother. 2008;61:46-53.

76. Keeney D, Ruzin A, Bradford PA. RamA, a transcriptional regulator, and AcrAB, an RND-type efflux pump, are associated with decreased susceptibility to tigecycline in Enterobacter cloacae. Microb Drug Resist. 2007;13:1-6.

77. Ruzin A, Keeney D, Bradford PA. AdeABC multidrug efflux pump is associated with decreased susceptibility to tigecycline in Acinetobacter calcoaceticus-Acinetobacter baumannii complex. J Antimicrob Chemother. 2007:59:1001-4

78. Dean CR, Visalli MA, Projan SJ, Sum P-E, Bradford PA. Efflux-mediated resistance to tigecycline (GAR-936) in Pseudomonas aeruginosa PAO1. Antimicrob Agents Chemother. 2003:47:972-8.

79. Chen Y, Hu DX, Zhang QJ, Liao XP, Liu YH, Sun J. Efflux pump overexpression contributes to tigecycline heteroresistance in Salmonella enterica serovar typhimurium. Front Cell Infect Mi. 2017;7.

80. Veleba M, De Majumdar S, Hornsey M, Woodford N, Schneiders T. Genetic characterization of tigecycline resistance in clinical isolates of Enterobacter cloacae and Enterobacter aerogenes. J Antimicrob Chemother. 2013;68:1011-8.

81. Lin $\mathrm{Y}-\mathrm{T}$, Huang $\mathrm{Y}-\mathrm{W}$, Huang $\mathrm{H}-\mathrm{H}$, Yang $\mathrm{T}-\mathrm{C}$, Wang F-D, Fung C-P. In vivo evolution of tigecycline-non-susceptible Klebsiella pneumoniae strains in patients: relationship between virulence and resistance. Int Antimicrob Ag. 2016:48:485-91.

82. Juan C-H, Huang Y-W, Lin Y-T, Yang T-C, Wang F-D. Risk factors, outcomes, and mechanisms of tigecycline-nonsusceptible Klebsiella pneumoniae bacteremia. Antimicrob Agents Chemother. 2016;60:7357-63. 
83. Fransen F, Melchers MJ, Meletiadis J, Mouton JW. Pharmacodynamics and differential activity of nitrofurantoin against ESBL-positive pathogens involved in urinary tract infections. J Antimicrob Chemother. 2016;71:2883-9.

84. Sandegren L, Lindqvist A, Kahlmeter G, Andersson DI. Nitrofurantoin resistance mechanism and fitness cost in Escherichia coli. J Antimicrob Chemother. 2008;62:495-503.

85. Ho PL, Ng KY, Lo WU, Law PY, Lai ELY, Wang Y, Chow KH. Plasmid-mediated oqXAB is an important mechanism for nitrofurantoin resistance in Escherichia coli. Antimicrob Agents Chemother. 2016;60:537-43.

Ready to submit your research? Choose BMC and benefit from:

- fast, convenient online submission

- thorough peer review by experienced researchers in your field

- rapid publication on acceptance

- support for research data, including large and complex data types

- gold Open Access which fosters wider collaboration and increased citations

- maximum visibility for your research: over $100 \mathrm{M}$ website views per year

At $\mathrm{BMC}$, research is always in progress.

Learn more biomedcentral.com/submissions 